\title{
Medical Certification of Cause of Death
}

\author{
Lt Col RB Kotabagi*, Col RK Chaturvedi+, Lt Col A Banerjee ${ }^{\#}$
}

\section{Background}

\begin{abstract}
Medical Certificate of Cause of Death, commonly called Death Certificate, is the most frequently issued certificate, at least by a government employed medical officer, if not by a private practitioner. It is common knowledge that many medical officers, even some of those with incomparable medical knowledge and expertise, do not fill up this document of immense medical and legal importance correctly. The reasons may be many, ranging from ignorance to indifference. Medical officers of Armed Forces Medical Services attending refresher courses (MOJC) have always requested the authors for a class on this topic. Considering these aspects, the authors have tried to clarify different issues concerning the question.
\end{abstract}

MJAFI 2004; 60 : 261-272

Key Words : Cause of Death; Mortality statistics; Registration of Births \& Deaths Act, 1969

\section{Introduction}

$\mathrm{B}$ irth and Death are the two most important events in the life of any individual as the person's existence starts at the moment of birth and ceases at the moment of death. A person has legal existence between the recorded timings of birth and death. Apart from this legal importance, recording of births and deaths creates vital basic data about a population group. Any planned activity concerning population viz: provisioning of basic necessities like food, housing, health care, education etc can be effective and successful only if this statistical information is correct. Hence, the necessity of registration of births and deaths. In India, with the passing of the Act - Registration of Births and Deaths Act - in 1969, registration of these events is mandatory. Registrar General of India is the highest official who compiles the information about deaths and births received from Registrars \& Sub-registrars of Births and Deaths at district level, Municipal Corporations and Municipalities of towns and Cantonment Boards of Military Cantonments.

Registration of not only the occurrence of death, but also its cause is equally important. Statistical analysis of causes of death forms important morbidity \& mortality statistics, which is the backbone of National Health Policy and Planning.

\section{Registration of Death}

For registering a death, identity of the deceased, date and time of death and cause of death are to be provided to the registering authorities. If any of these details are not available death can not be registered.
Providing these details is not a difficult task for a medical officer when the death is of one of his patients suffering from a known disease, who dies attended by the doctor. In some such deaths, the cause of death i.e. the disease which the individual was suffering from, might not have been established at the time of death due to various reasons. However, the same can be ascertained by a clinical post mortem examination with the consent of the relatives. The situation may not be so simple in medico-legal cases. Most of these deaths are unattended, hence, exact time and date is not known and since terminal symptomatology is not available, cause of death can not be decided. Many times the identity of the deceased is also not known. Hence, a medico-legal postmortem is carried out, as a part of the inquest, to establish the cause of death, time of death and identity of the deceased. Out of these, the cause of death can be certified by the medical officer alone, who carries out the postmortem. Identity and time of death are primarily established by the investigating police officer, however, the medical officer doing the autopsy collects whatever data he can during the autopsy to establish these two and thus helps the police officer. When all the three facts are available, the death is registered with the appropriate authority.

\section{Role of Medical Officer}

When confronted with 'death' of a person, the medical officer has two tasks at hand. The first is to diagnose the occurrence of death and declare the person dead. The second is to decide the cause of death and certify the same. The first task has to be carried out in all situations i.e. deaths due to diseases, old age, suicide,

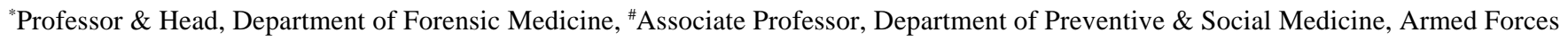
Medical College, Pune-411 040, ${ }^{+}$Senior Registrar \& OC Troops, Command Hospital (Southern Command), Pune-40. 
homicide and accidents etc. Having decided that the person is dead, he proceeds to fill up "Death Report" in the capacity of informant. Both the formats of death report viz Legal Information and Statistical Information, are to be filled up for each death. The formats are appended to this article as appendices 'A' and 'B'. Both these are to be sent to the death registering authority along with the medical certificate of cause of death.

The second task at hand i.e. issuing Medical Certificate of Cause of Death, is done immediately after deciding the person is dead, by the same medical officer who has declared the person dead, provided the medical officer is absolutely certain of the cause of death and if it is a natural death. Deaths due to old age and deaths due to any naturally occurring disease or its complication are Natural Deaths. Correct knowledge of the cause of death is essential as future course of action is different if the death is other than natural or cause of death is not known/doubtful. The form used for certification of cause of death in some countries like UK includes a statement from the certifying doctor that he has attended the deceased during his terminal illness or within 14 days prior to his death [1]. This indirectly means that if the doctor has attended the deceased only during his terminal moments or was called after death, he can not certify the cause of death as he will not have certain knowledge of the same. This time limit of 14 days is applicable even if the individual is a regular patient of the doctor and was suffering from a known chronic illness, as the cause of death may still be different. It is better that even medical officers practising in India, presume that the ruling exists in India as well.

If the death is not clearly of natural category i.e.other than natural or cause not known/doubtful, the medical officer having carried out first task i.e. declaration of death, informs the police of occurrence of the death for further course of action. He will not issue a medical certificate of cause of death. Since the bottom portion of the medical certificate of cause of death is required to be produced by the relatives at the cremation ground/ the municipality office giving permission for cremation, non-issuance of the same will automatically ensure that the body can not be cremated.

Having taken over the custody of the dead body, the investigating police officer proceeds with inquest and the cause of death is decided after the medico-legal postmortem is carried out as part of the inquest.

This system ensures that the body is not disposed off without necessary investigations by the police into the cause and circumstances of death, when the death is due to other than natural causes. The medical certificate of cause of death is filled up either by the medical officer who carries out the medico legal autopsy or by the hospital administrative authorities immediately on conclusion of the autopsy. Since the medico legal postmortem is carried out on orders of the investigating police officer/coroner/magistrate, the medical certificate of cause of death is forwarded to these authorities only, by the certifier, and not directly handed over to the relatives of the deceased. The police authorities will handover the relevant (bottom) portion of the certificate to the relatives while handing over the dead body to them, which is done when the investigating officer decides that the dead body is no more required for investigations. A copy is forwarded to the death registering authorities by the police along with the death report forms.

In addition, certain other points to be kept in mind by the medical officer concerning the issuance of medical certificate of cause of death, are [2]:-

(a) He should not delay, for any reason, issuing the medical certificate of cause of death, once he is sure of the cause of death.

(b) He can not charge any fees for issuing this certificate.

(c) He should not withhold issuance of medical certificate of cause of death even if his dues have not been cleared by the relatives.

(d) No medical officer should sign medical certificate of cause of death in advance (i.e. before the individual has died) or without viewing and examining the dead body personally.

\section{Medical Certificate of Cause of Death - How to fill up}

Since medical officer is the sole authority in deciding the cause of death, proper documentation of cause of death by him is of utmost importance. Wrong diagnosis or incorrect filling up of the certificate will result in gross error in mortality statistics, thus directly affecting formulation of National Health Policy. In addition, the certified cause of death is subjected to legal scrutiny in medico-legal deaths. If the opinion given by the medical officer fails to withstand the acid test of cross examination, it is not only embarrassing for the medical officer but also may result in doubts being raised about his professional competence. Despite utmost importance being given in the curriculum, many MBBS doctors submit improperly/incorrectly completed medical certificates of cause of death either due to ignorance or casual attitude. There have been media reports and studies which have revealed that approximately 50-60\% of medical certificates of cause of death submitted to death registering authorities are incorrectly filled up. The matter is of serious concern. 
Two separate formats, one for peri-natal deaths and another for all other deaths, exist for medical certification of cause of death. The one to be used in non peri-natal deaths has two variants for hospital deaths (Appx 'C') and non-hospital deaths (Appx 'D'). The difference between the two is minimal. The form to be used in peri-natal deaths is appended as Appx ' $E$ '. The most important portion naturally is the portion where cause of death is mentioned.

The first portion of the form gives the available information about the personal particulars of the deceased including date and time of death. As regards the date and time of death, the date and time at which the certifier decides that the individual is dead (somatic death), is the date and time of death. Since the medical officer can not declare a person dead without attending and examining him, this entry will be of the time when he has first seen the individual dead, irrespective of when the death has occurred. For example, if the old man has died during his sleep at night and medical officer examines him at 0600 hours on next morning, the individual is declared to have died at 0600 hours. However, all such cases of deaths, unattended by a medical officer, are to be reported as medico-legal deaths. The actual time of death will then be decided during the inquest and post mortem examination along with the cause of death. Since the medical certificate of cause of death is filled after the post mortem examination, the legal time of death will be registered as that decided after the inquest. Similarly, dilemma may arise in situations of prolonged attempts to revive a person thought to be in suspended animation. The time of death then is when revival measures are considered futile and stopped. Thirdly, some hospitals have a rule that the dead body, in case of a ward death, is to be retained in the ward for 2 hours and is to be examined for signs of life frequently during that period, before being sent to mortuary. This is to ensure the death is not wrongly diagnosed, not an uncommon occurrence especially during epidemics, mass disasters etc. Under such circumstances, the decision of the certifying medical officer is final and the time of death can be entered as anytime during those two hours when the medical officer is convinced of its occurrence.

If the identity of the deceased is not known then the name will be entered as "Unknown" in all the documents including the medical certificate of cause of death and will be replaced by the correct information when available.

In 1967, the twentieth World Health Assembly defined the causes of death to be entered on the medical certificate of cause of death as "all those diseases, morbid conditions or injuries which either resulted in or contributed to death and the circumstances of the accident or violence which produced any such injuries" [3]. In a given situation more than one of the above conditions may be present, which may be completely unrelated to each other or they may be causally related to each other, i.e. one leading to the other, thus establishing a sequence. The disease or circumstances of accident/violence, which started the chain, is the Underlying Cause of Death and the subsequent events in the chain are called as Antecedent Cause and Immediate Cause of death, in that order. The entire sequence gives the complete picture of the cause of death.

Example: In a case of Diabetes Mellitus, dying of septicaemia due to gangrene of a limb-

(a) Immediate Cause : Septicaemia

(b) Antecedent Cause : Gangrene of Limb

(c) Underlying Cause : Diabetes Mellitus

If the individual was suffering from any other disease which is not related to the underlying cause and hence can not be part of the sequence, but, in the opinion of the certifier, has contributed to death, such a condition too is to be recorded in the certificate. However, if the co-existing disease has not contributed to death, it has no place in the medical certificate of cause of death. Thus the certificate, unlike his medical records, is not a list of all diseases which the individual was suffering from at the time of death.

The above-mentioned details about the cause of death are entered in a definite format, approved by WHO. Information under I pertains to the underlying cause of death, antecedent cause of death and immediate cause of death, written from below upwards, clearly depicting the sequence of events ending with immediate cause written under (a). The sequence will give the order of relationship between events leading to death both with respect to time and etiological or pathological relationship. The importance of recording the sequence correctly lies in the fact that appropriate strategies can be adopted to cut the chain at its most vulnerable point and thus prevent death. The original format, approved by WHO, had only (a), (b) and (c) under I, but as per recommendations of Forty-Third World Health Assembly 1990, an additional line (d) has been added below (c) [4].

Since mistakes in filling up Part I can render the certificate useless, certain points are to be kept in mind by the certifier:

(i) Obviously, it has to be filled up by the doctor who has full knowledge of the events which lead to death.

(ii) The names of the diseases should be written in full 
and legibly, preferably in block capital letters, along with ICD code number. Abbreviations and short forms of diseases are not to be used as they are likely to lead to confusion in the statistical office.

(iii) Terminal events like circulatory failure, respiratory failure etc and modes of dying should be avoided as they are no more than signs of death and provide no useful information as to the underlying disease process. If at all entered, the disease which led to them must be entered in the next line. They can not be the sole entries.

(iv) The underlying cause of death which started the sequence should be the last entry under I. Consequently, if there is no chain of events and underlying cause is the only event, it should be entered under (a) as it is both the immediate \& underlying cause. Evidently, line (a) must always have an entry. Due thought should be given to the last entry under I as it is picked up for statistical purposes as underlying cause of death.

Example: When the death is due to lobar pneumonia, it is the Underlying, Antecedent and Immediate cause of death. Hence LOBAR PNEUMONIA will be entered under (a) and (b), (c) and (d) will be left vacant.

(v) Death due to old age is also a natural death and the underlying cause of death then is entered as Senility under I (a). However, senility as underlying cause of death is to be entered only when no other disease or its complication has caused death [5].

(vi) Although, it is a general rule that only one condition is to be entered on each line ( $a, b, c, d)$, when the sequence consists of more than 4 entries, more than one condition can be entered on one line, of course maintaining the correct causal relationship. This will retain the internationally accepted form of the certificate. However, even if the alternative of increasing the lines beyond ' $\mathrm{d}$ ' is resorted to, the last entry must be the underlying cause [6].

Having entered the conditions sequentially, the duration of existence of each one of them is to be reflected under the heading "Interval between onset and death. Approx". This entry will give the chronology of events and thus ensure the correctness of the sequence.

Most formats of death certificates require the certifier to provide certain epidemiological information about the deceased. Having furnished the details about the cause of death, information about associated pregnancy \& delivery is asked. Obviously these columns are not applicable if the deceased is a male and the entries have to be made even if the cause of death is in no way related to pregnancy or delivery. This information is sought, considering the vulnerability of women to death during pregnancy and delivery. Similarly opinion about the manner of death i.e. accident / suicide / homicide is to be provided if possible. However, the most important part of the certificate is the portion giving details of cause of death.

Having provided all the available information to the best of his knowledge, the certifier signs the certificate giving his name, qualifications, designation and registration number. The date and time of signature will be the same as that of death mentioned in the beginning of the certificate, except in cases where the cause of death has been certified after an autopsy.

The bottom portion of the medical certificate of cause of death is to be filled up by the certifier, detached and handed over to the relatives. This document enables them to get the municipal permission for cremation as well as acts as reference to obtain the extract of the death register (Death Certificate) from the registering authority. It may be noted that this portion, handed over to the relatives does not mention the medical cause of death. Even the Death Certificate issued by the registering authority does not mention the medical cause of death. This procedure is adopted to maintain confidentiality of information of the cause of death in accordance with section 17(1) (b) of Registration of Births \& Deaths Act of 1969. Hence, the certifier should send the medical certificate of cause of death along with death report forms to the registering authority directly. Thus the medical cause of death is entered and available only in the Death Register maintained by the registering authority. The convenient practice of sending a copy of the entire medical certificate of cause of death through the relatives to the registering authority violates the above mentioned section of the act.

Section 17(1) (b) of Registration of Births \& Deaths Act also states that any person can obtain the extract from the Death Register of registering authority (death Certifier) on payment of the laid down fees along with an application.

Sample of a Death Certificate issued by Delhi Municipal Corporation is enclosed as Appx 'F'. Note that the medical cause of death is not mentioned in it.

Ideally, the certificate of Cause of Peri-natal death Appx ' $E$ ' - is to be used for all deaths of neonates up to the age of 28 days after birth [6]. It should provide detailed information about present and past obstetrical history of the mother, medical information about the deceased child as well as siblings and the mother. Considering the multi-factorial influence on peri-natal deaths, this specific form is to be used while reporting peri-natal deaths, which enables a detailed statistical 
analysis of such deaths.

As per Army Order (AO) 1/2003/MP, death certificate in case of battle casualties is issued by AHQ AG's Branch for officers and units / record offices in case of JCOs and OR. Details of administrative action to be taken is mentioned in the AO. For battle casualties and battle accidents, the decision of the commanding officer, arrived at in consultation with the regimental medical officer, as regards the cause of death is final and they are not medico-legal deaths. All physical casualties are medico-legal cases and will be reported to civil police authorities for further action. If the civil police set up is not available in the area, a military inquest will be held on similar lines - Army Order (AO)20/2001/ DV which has replaced AO 54/75, refers.

\section{Conclusion}

Considering the importance of correct certification of medical cause of death and death registration, the foregoing account of the different aspects of the same, has tried to clarify the difficulties and doubts encountered by the registered medical practitioner while certifying death. However, understanding the pathology of the underlying and contributory causes of death is essential for the certifier. As a corollary, rarely, two medical officers of different levels of knowledge and expertise may differ on the entries to be made in a given case. It suffices if the cause of death is certified in accordance with the knowledge of the certifier ("To the best of my knowledge").

As far as the Armed Forces Medical Services are concerned, the present AFMSF-93 Part I, needs to be modified incorporating the portion to be handed over to the relatives and the present practice of handing over a copy of the entire certificate should be stopped as it violates the confidentiality provision of Registration of Births and Deaths Act (1969).

The present practice of using AFMSF 93 Part I in cases of found dead or sudden death cases needs to be changed. Since the requirement is only to declare the person dead, the same can be done in the medical case sheet and AFMSF 93 Part I should be filled up after the cause of death is established by medico-legal post mortem. If required, a separate form may be introduced by the AHQ for the purpose of declaring the person dead in such cases. Till such a procedural change is introduced the concerned hospital authorities should forward an amended AFMSF 93 Part I after the correct cause of death is established by medico-legal post mortem to all the authorities to whom AFMSF 93 Part I was sent at the first instance.

\section{References}

1. Simpson K. Forensic Medicine: $8^{\text {th }}$ ed., London: English Language Book Society and Edward Arnold (Publishers) Ltd, 1979;217-29.

2. Govt of India, Ministry of Home Affairs; Registration of Births and Deaths Act - 1969. Section 10(3).

3. World Health Organisation; Twentieth World Health Assembly Proceedings - 1967.

4. DGAFMS, Director General Armed Forces Medical Services Medical Memorandum 153; Medical Certification of Cause of Death, New Delhi; Ministry of Defence - 2002.

5. Office of the Registrar General of India, Vital Statistics Division: Physicians' Manual on Medical Certificate of Cause of Death; $4^{\text {th }}$ ed, 2000, New Delhi: Ministry of Home Affairs, Govt of India.

6. Bernard K.Simpson's Forensic Medicine: $10^{\text {th }}$ ed, London: English Language Book Society, 1991;12-27. 


\section{राष्ट्रीय राजधानी क्षेत्र दिल्ही सरकार \\ GOVT OF NATIONAL CAPITAL TERRITORY OF DELHI \\ मृत्यु प्रतिवेदन \\ DEATH REPORT \\ कानूनी सूचना \\ Legal Information \\ यह भाग मृत्यू रजिस्टर के साथ जोड़ा जाये \\ This part to be added to the Death Register \\ सूचना देने वाले द्वारा भरा जाये (To be filled by the information)}

1. मृत्यु तिथि : (मृत्यु होने का सही दिन,

महीना और वर्ष लिखें जैसे 1-1-2000)

Date of Death : (Enter the exact day, month and year the death took place e.g., 1-1-2000)

2. मृतक का नाम :

(पूरा नाम जैसा कि प्राय: लिखा जाता है)

Name of the Deceased

(Full name as usually written)

3. मृतक का लिंग : (पुल्टिंग या स्रीलिंग लिखें संक्षिप्त रूप न लिखें)

Sex of the deceased :

(Enter "'male" or "'female" do not use abbreviation)

4. मृतक की आयु : (यदि मृतक की आयु 1 वर्ष से अधिक हो तो आयु पूर्ण वर्षों में, एक वर्ष से कम हो तो पूर्ण महीनों में, एक महीने से कम हो तो पूर्ण दिनों में और यदि 1 दिन से भी कम हो तो पूर्ण घंटों में लिखें)

Age of the deceased : (if the deceased was over 1 year of age, give age in completed years. If the deceased was below 1 year of age, give age in months, and if below 1 month give age in completed number of days, and if below one day, in hours)

5. मृत्यु का स्थान : (निम्न में से 1,2 या 3 पर सही का निशान लगायें और अस्पताल/संस्था का नाम या घर का पता जहाँ मृत्यु हुई हो लिखें यदि किसी अन्य स्थान पर हुई हो तो उस जगह का नाम लिखें)

Place of death : (Tick the appropriate entry 1,2 or 3 below and give the name of the Hospital/Institution or the address of the house where the death took place. If other place, given location)
1. अस्पताल/संस्था
नाम
Hospital/Institution
Name :
2. घर
पता :
House
Address :

3. अन्य स्थान

Other Place

6. सूचना देने वाले का नाम :

Information's name :

पता :

Address :

(कॉलम 1 से 17 भरने के बाद ही सूचना देने वाला हस्ताक्षर और दिनांक लिखेगा)

(After completing all columns to 17, information will put date and signature here:)

दिनांक :

सूचना देने वाले के हस्ताक्षर अथवा बायें अंगूठे का निशान

Date :

Signature or left thumb mark of the informant

पंजीकरण संख्या :

Registration No :

पंजीकरण यूनिट :

Registration Unit :

शहर/गांव :

Town/Village :

विवरण : (यदि कोई हो)

Remarks : (if any)

\section{पंजीकार द्वारा भरा जाये । (To be filled by the Registrar)}

पंजीकरण तिथि :

Registration Date :

जिला :

District : 


\section{राष्ट्रीय राजधानी क्षेत्र दिल्डी सरकार \\ GOVT OF NATIONAL CAPITAL TERRITORY OF DELHI मृत्यु प्रतिवेदन \\ DEATH REPORT \\ सांख्यिकीय सूचना \\ Statistical Information \\ यह भाग अलग करके सांख्यिकीय कार्यवाही हेतु भेजा जाये}

This part to be detached and sent for statistical processing

सूचना देने वाले द्वारा भरा जाये (To be filled by the information)

7. मृतक के निवास का शहर या गांव (स्थान जहाँ मृतक वास्तव में रहता था । वह उस स्थान से अलग हो सकता है । जहाँ मृत्यु हुई हो । घर का पता लिखना आवश्यक नहीं है)

Town or village of Residence of the deceased : (Place where the deceased actually lived. This can be different from the place where the death occurred. The house address is not required to be entered).

अ. शहर या गांव का नाम :

Name of Town/Village :

ब. क्या यह शहर या गांव है? (निम्न में से एक पर सही का निशान लगाये)

$\begin{array}{ll}\text { 1. शहर/Town } & \text { 2. गांव/Village }\end{array}$

स. जिले का नाम/Name of District :

द. राज्य का नाम/Name of State :

8. धर्म : (निम्न में से किसी एक पर सही का निशान लगायें)

Religion : (Tick the appropriate entry below)

1. हिन्दू/Hindu 2. मुसलमान/Muslim 3. ईसाई/Christian 4. अन्य कोई धर्म (धर्म का नाम लिखें)

Any other religion : (Write the name of the religion)

9. मृतक का व्यवसाय : (यदि कोई व्यवसाय नहीं तो शून्य लिखें)

Occupation of the deceased : (if no occupation write "'Nil")

10. मृत्यु से पहले ली गई चिकित्सा सहायता की किस्म :

(निम्न में से एक पर सही का निशान लगायें)

Type of medical attention received before death :

(Tick the appropriate entry below)

1. संस्थागत

Institutional

2. संस्था के अलावा अन्य ली गई चिकित्सा सहायता

Medical attention other than institution

3. कोई भी चिकित्सा सहायता नहीं

No medical attention

11. क्या मृत्यु का कारण चिकित्सा प्रमाणित था? (निम्न पर सही का निशान लगायें)

Was the cause of death medically certified?

(Tick the appropriate entry below)

1. हां/Yes

2. नहीं/ No

12. बीमारी का नाम या मृत्यु का वास्तविक कारण : (सभी प्रकार की मृत्यु के लिये चाहे चिकित्सीय, प्रमाणित है या नहीं)

Name of Disease or Actual Cause of Death : (For all deaths irrespective of whether medically certified or not)

13. महिला मृत्यु की स्थिति में मृत्यु गर्भ के दौरान, प्रसूति के समय या गर्भावस्था की समाप्ति के 6 सप्ताह के भीतर हुईः (निम्न पर सही का निशान लगाये)

In case this is a female death, did the death occur while pregnant, at the time of delivery or within 6 weeks after the end of pregnancy :

(Tick the appropriate entry below)

1. हां/Yes

2. नहीं/No

14. यदि धुम्रपान की आदत थी तो कितने वर्षो से?

If used to habitually - for how many years?

15. यदि किसी भी प्रकार के तम्बाकू चबाने की आदत थी तो कितने वर्षो से?

If used to habitually chew tobacco in any form - for how many years? 
16. यदि किसी भी रूप में (पान मसाला सहित) सुपारी चबाने की आदत थी तो कितने वर्षों से?

If used to habitually chew area nut in any form (including masala) - for how many years?

17. यदि शराब पीने की आदत थी तो कितने वर्षों से?

If used to habitually drink alcohol - for how many years?

(सभी कॉलम भरने के बाद बायीं ओर हस्ताक्षर करे)

(Columns to be filled are over. Now put signature at left)

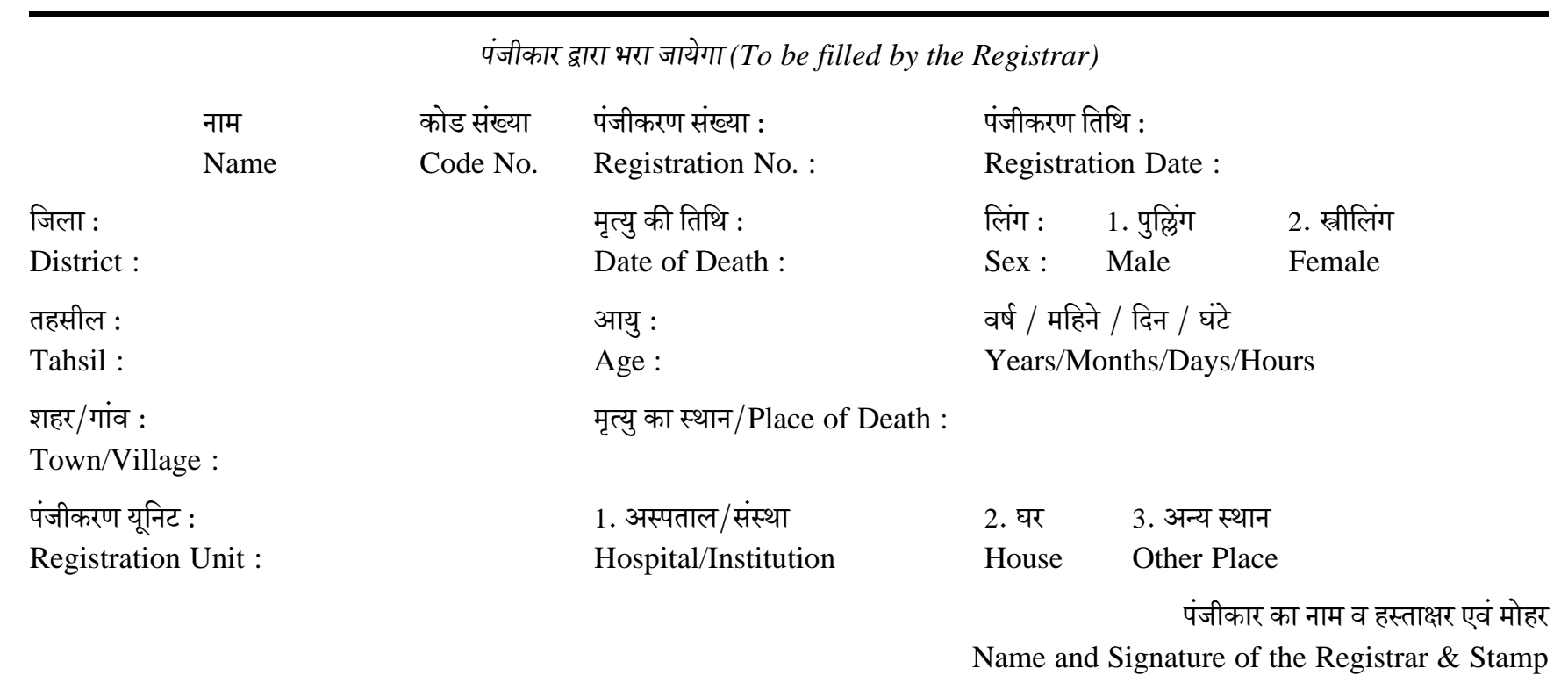




\title{
GOVERNMENT OF NATIONAL CAPITAL TERRITORY OF DELHI
}

\author{
फार्म संख्या 6 \\ (नियम संख्या 8 देखिए) \\ Form No. 6 \\ (See Rule 8) \\ मृत्यु प्रमाण-पत्र \\ (धारा 12/17 के अन्तर्गत दिया गया) \\ Death Certificate \\ (Issued under Section 12/17)
}

यह प्रमाणित किया जाता है कि निम्नलिखित सूचना मृत्यु के मूल लेख से ली गई है जो कि (स्थानीय क्षेत्र)

तहसील

जिला

राज्य

के रजिस्टर में उक्लिखित है ।

This is certify that the following information has been taken from the original record of death which is the register for (Local Area)

of Tehsil

of District

of State

नाम/Name

लिंग/Sex

मृत्यु का दिनांक/Date of Death

मृत्यु का स्थान/Place of Death

पंजीकरण संख्या/Registration No.

पंजीकरण दिनांक/Date of Registration

प्राधिकारी के हस्ताक्षर

Signature of issuing authority

मोहर/Seal

दिनांक/Date

मृत्यु की स्थिति में पंजीकरण में दिए गये मृत्यु के कारणों का कोई ब्यौरा नहीं दिया जायेगा । धारा 17 (1) के परन्तुक को देखिए ।

No disclosure shall be made of particulars regarding the cause of death as entered in the register. See proviso to Section 17 (1) 
FORM NO. 4A

(See Rule 7)

\section{MEDICAL CERTIFICATE OF CAUSE OF DEATH}

(For non-institutional deaths. Not to be used for still births)

To be sent to Registrar along with Form No. 2 (Death Report)

I hereby certify that the person Shri/Smt/Km

son/wife/daughter of

resident of

was under my treatment from

A.M./P.M.

and he/she died on

at

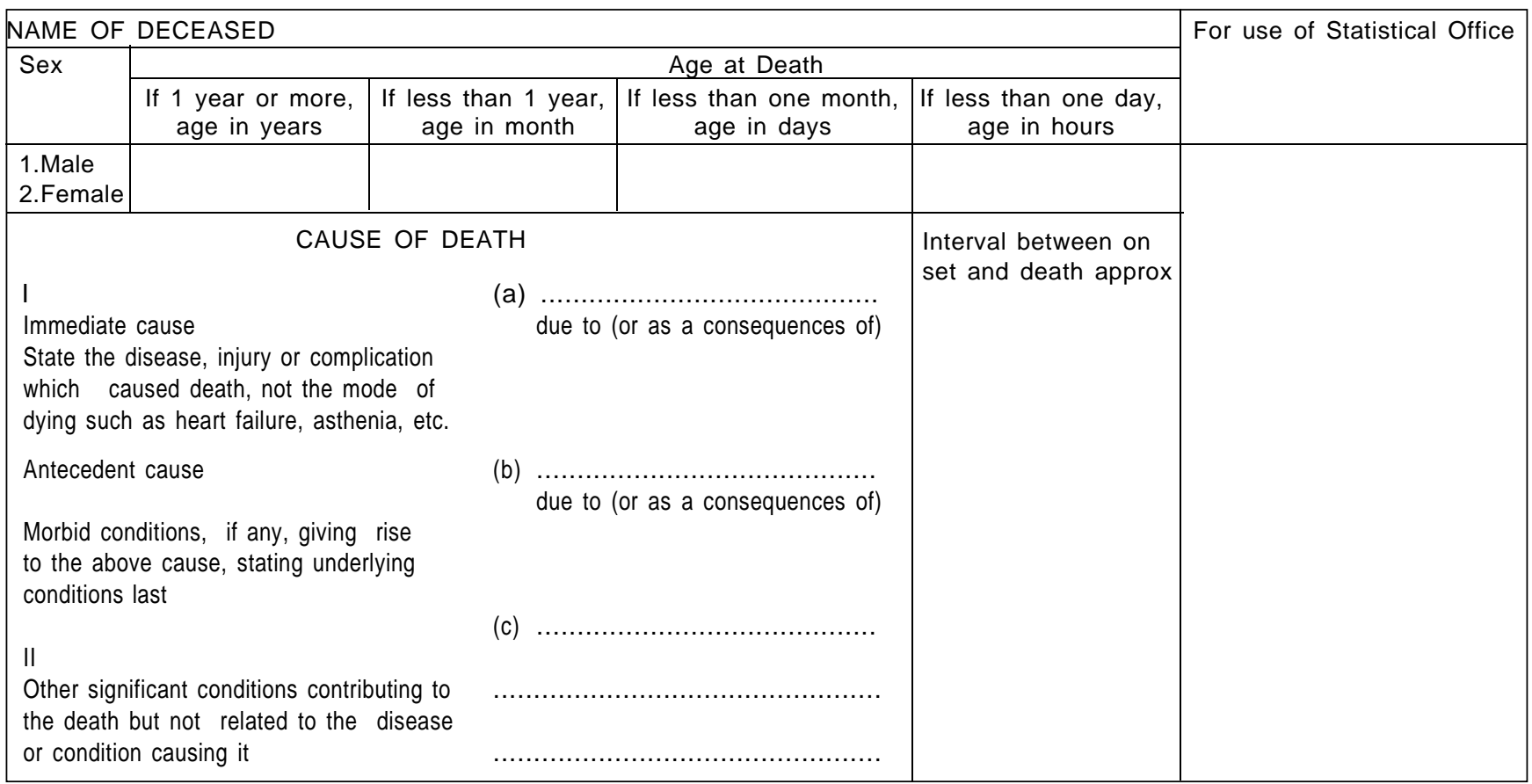

If deceased was a female, was pregnancy the death associated with?

If yes, was there a delivery?

1. Yes 2. No

1. Yes 2. No

Name and signature of the Medial Attendant certifying the cause of death

Date of verification

(To be declared and handed over to the relative of the decease)

Certified that Shri/Smt/Kum

S/W/D OF Shri

$\mathrm{R} / \mathrm{O}$.

was under my treatment from

to

and he/she expired on

at

A.M./P.M

Doctor

(Medical Supdt.

Name of Hospital) 


\section{FORM NO. 4 \\ (See Rule 7) \\ MEDICAL CERTIFICATE OF CAUSE OF DEATH}

(Hospital In-patients. Not to be used for still births)

To be sent to Registrar along with Form No. 2 (Death Report)

Name of the Hospital

I hereby certify that the person whose particulars are given below died in the hospital in Ward No.

at ........ AM/PM

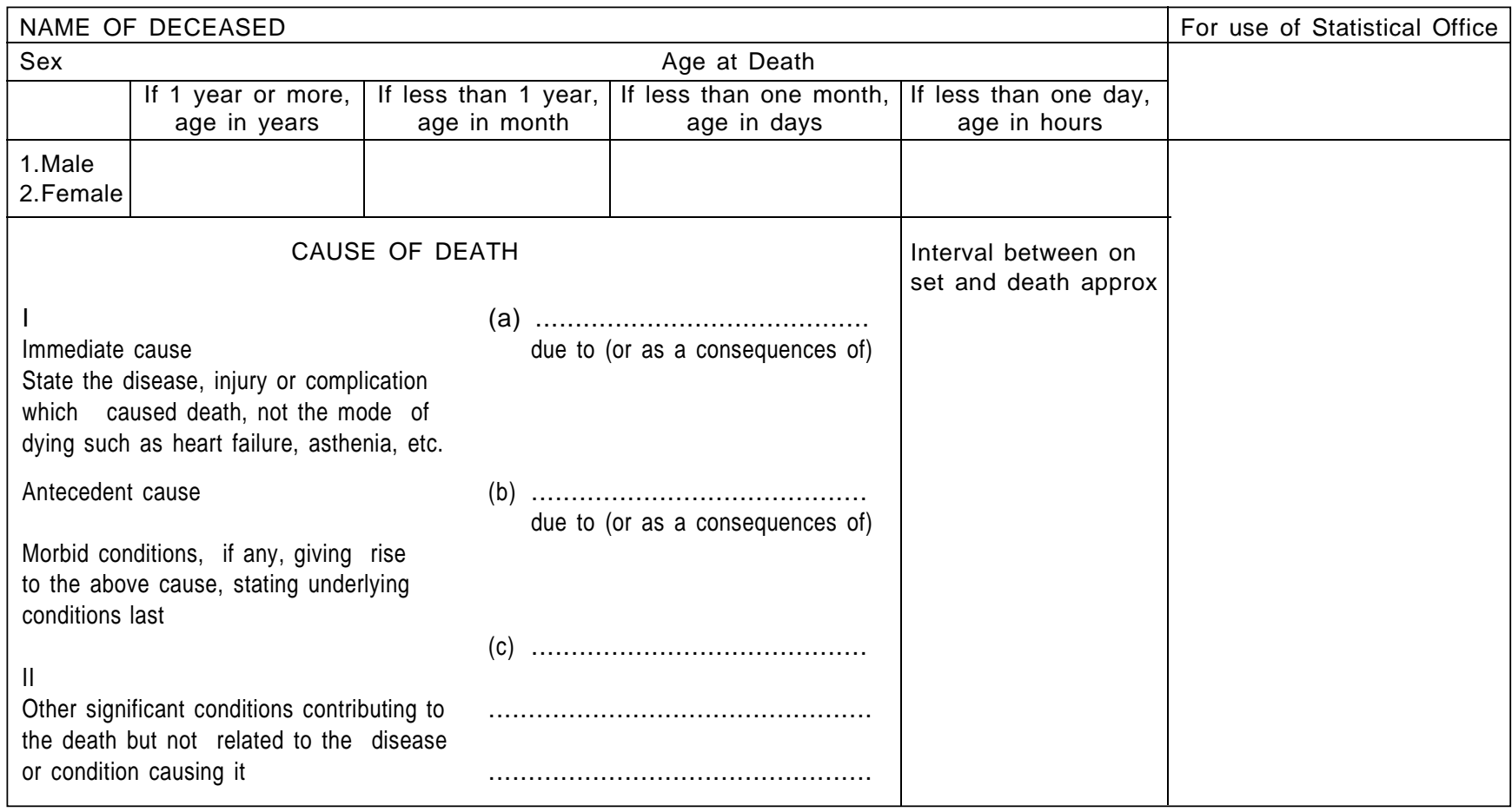

\section{Manner of Death}

How did the injury occur?

1. Natural 2. Accident 3. Suicide 4. Homicide

5. Pending investigation

If deceased was a female, was pregnancy the death associated with?

If yes, was there a delivery? 1. Yes 2. No

1. Yes 2. No

Name and signature of the Medial Attendant certifying the cause of death

Date of verification

(To be declared and handed over to the relative of the decease)

Certified that Shri/Smt/Kum.

S/W/D OF Shri

$\mathrm{R} / \mathrm{O}$ was admitted to this hospital on

and expired on 


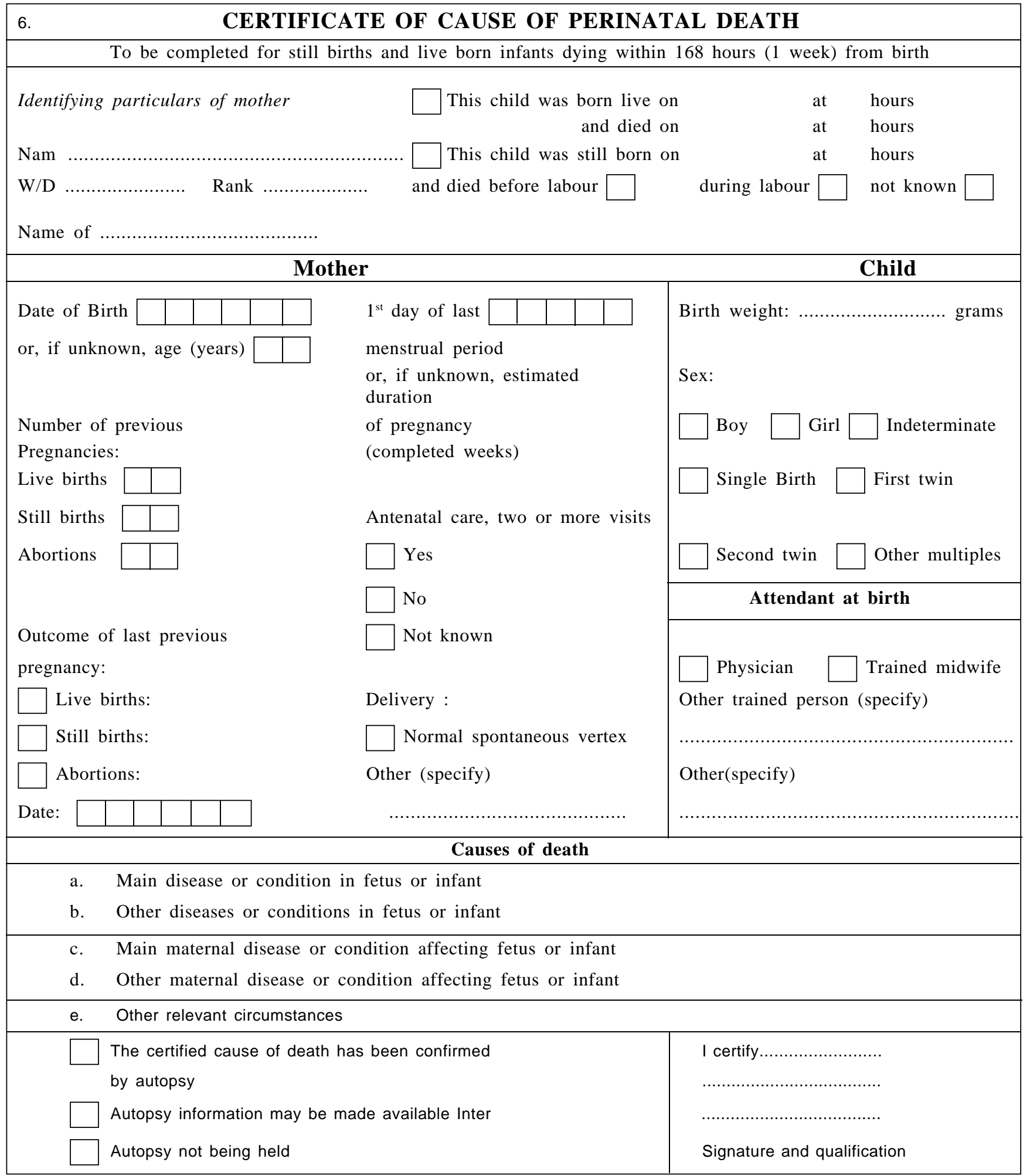

